(u 2-kh ch.) [Ukrainian language. Primer: textbook. for 1 class. lock total. among. education (in 2 parts)]. Part. 1. Kharkiv, 80 p.; Bolshakova I., \& Prystinska, M. (2018). Ukrainska mova. Bukvar : pidruch. dlia 1 kl. zakl. zahal. sered. osvity (u 2-kh ch.) [Ukrainian language. Primer: textbook. for 1 class. lock total. among. education (in 2 parts)]. Part. 2. Kharkiv, 80 p. [in Ukrainian].

4. Yermolenko, S. (2007). Mova i ukrainoznavchyi svitohliad [Language and Ukrainian worldview]. Kyiv, pp. 318-360. [in Ukrainian].

5. Kalyta, N. (2019). Formuvannia osnov natsionalnopatriotychnoho vykhovannia $\mathrm{v}$ uchniv pochatkovoi shkoly [The formation of bases of national patriotic educationof primary school pupils].Youth \& market, No. 10, pp. 30-34. [in Ukrainian].

6. Pro Natsionalnu doktrynu rozvytku osvity: Ukaz Prezydenta Ukrainy vid 17 kvit. 2002 No. 347/2002 (2004). [On the National Doctrine of Educational Development: Presidential Decree of 17/04. 2002. p. No 347/2002]. Legislative acts of Ukraine on education: as of April 1.2004
Verkhov. Council of Ukraine, Committee on Science and Education. Kyiv, pp. 279-294. [in Ukrainian].

7. Nova ukrainska shkola [New Ukrainian school]. Available at: https://mon.gov.ua/storage/app/media/ zagalna\%20serednya [in Ukrainian].

8. Oliiar, M. P. (2015). Teoriia i praktyka formuvannia komunikatyvno-stratehichnoi kompetentnosti maibutnikh uchyteliv pochatkovykh klasiv [Theory and practice of forming communicative-strategic competence of future primary school teachers]. Ivano-Frankivsk, 475 p. [in Ukrainian].

9. Symonenko, T. (2000). Shliakhy i zasoby formuvannia natsionalno-movnoi osobystosti $\mathrm{v}$ shkoli [Ways and means of forming a national-language personality in school]. Ukrainian language and literature at school, No. 1, pp. 8-10. [in Ukrainian].

10. Stelmakhovych, M. (1993). Etnopedahohichni osnovy metodyky ukrainskoi movy [Ethnopedagogical bases of Ukrainian language methodology]. Ukrainian language and literature at school, No. 5-6, pp. 19-23. [in Ukrainian].

Стаття надійшла до редакції 22.09.2021

УДК 378.147.091.31-059.1]:37.04(045)

DOI:

Христина Шапаренко, доктор педагогічних наук, доцент, декан факультету дошкільної $і$ спеціальної освіти та історіі Комунальний заклад "Харківська гуманітарно-педагогічна академія" Харківської обласної ради

\title{
ТЕОРЕТИЧНЕ ОБГРУНТУВАННЯ ПЕДАГОГІЧНИХ УМОВ ФОРМУВАННЯ ІНДИВІДУАЛЬНОЇ ОСВІТНЬОЇ ТРАЄКТОРІЇ МАЙБУТНІХ ПЕДАГОГІВ В ПРОЦЕСІ ПРОФЕСІЙНОӤ ПІДГОТОВКИ
}

У статті розглянуто особливості професійної підготовки майбутніх педагогів у спеціально створених для неї умовах. Проаналізовано сучасні підходи до підвищення якості підготовки студентів у системі вищоі професійної освіти із використанням індивідуально-орієнованих технологій, до реалізації педагогічних умов професійної підготовки як чинників, від яких залежсить ефективність функціонування педагогічної системи. Доведено, що при визначенні педагогічних умов формування індивідуальної освітньої траєкторії здобувача освіти слід врахувати той факт, щзо власний шлях освіти вибудовується для кожного студента стосовно кожної досліджуваної ним освітньої галузі, специфіку через вибір професії відповідно до особистісних та індивідуальними властивостей, забезпечення якості ії освоєння, сходження до вершин професіоналізму та психологічного супроводу професійного становлення.

Ключові слова: професійна підготовка; індивідуальна освітня траєкторія; освітній прочес; майбутній педагог; індивідуалізачія освіти; педагогічні умови.

Jim. 11.

Khrystyna Shaparenko, Doctor of Sciences (Pedagogy), Associate Professor, Professor of the Theory and Methods of Preschool Education Department,

Dean of the Faculty of Preschool, Special Education and History, Municipal Establishment "Kharkiv Humanitarian Pedagogical Academy" of Kharkiv Regional Council

\section{THEORETICAL EXPLANATION OF PEDAGOGICAL CONDITIONS OF OUTLINIG INDIVIDUAL EDUCATIONAL TRAJECTORIES OF FUTURE TEACHERS IN THE PROCESS OF PROFESSIONAL TRAINING}

The article deals with the peculiarities of professional training of future teachers in specially created conditions. The article analyzes modern approaches to improving the quality of student training in the system of higher professional education by means of individual-oriented technologies, to implementing pedagogical conditions 
of professional training as factors on which the effectiveness of the pedagogical system depends. It is proved that in determining the pedagogical conditions for forming a student's individual educational trajectory, it should be taken into account that an educational roadmap is built for each student in relation to each educational topic one studies, specificity by choosing profession in accordance with personal and individual characteristics, ensuring the quality of development, reaching high professionalism and psychological support.

It is determined that educational process based on individual trajectories involves teacher-students interaction in which there is gradual design and implementation of individual educational goals, together with constant diagnosis to identify and monitor individual educational goals in order to detect and monitor student's individual features by implementing reflection and correction of individual educational roadmaps and complying with necessary pedagogical conditions. The pedagogical conditions for building a student's individual educational trajectory are outlined as well as pedagogical support of creating an individual educational trajectory of future teachers in the process of professional training; strengthening practical orientation of educational process; increasing the amount of independent work of students.

Keywords: professional training; individual educational trajectory; educational process; future teacher; individualization of education; pedagogical conditions.

П остановка проблеми. Перед вищою педагогічною освітою постійно висувається завдання підготовки фахівців творчих, відповідальних, ініціативних, готових до подолання складних проблем у майбутньому. При цьому особливої актуальності і цінності набуває розвиток у студентів навичок самостійної навчальної діяльності, які дозволять їм, у міру необхідності, самостійно оволодівати новими знаннями, вибудовуючи індивідуальну освітню траєкторію в процесі професійної діяльності і після закінчення закладу освіти протягом усього життя.

В освітній практиці постійно втілюються новітні технології розвивального навчання, що дає змогу розв'язати питання відкритості, гнучкості та високої ефективності освітнього процесу на будьякому етапі. Водночас урахування індивідуальних можливостей, здібностей і потреб особистості в системі професійної підготовки досить часто розуміється формально.

Численні дослідження особливостей професійної підготовки майбутніх педагогів доводять, що педагогічна система функціонує більш результативно в спеціально створених для неї умовах. Підтримуючи це твердження, необхідне виявлення педагогічних умов, що забезпечують ефективне формування індивідуальної освітньої траєкторії майбутніх педагогів у процесі професійної підготовки.

Аналіз останніх досліджень і публікацій. Загальні питання підвищення якості підготовки студентів у системі вищої професійної освіти із використанням індивідуально-орієнованих технологій знайшли відображення у роботах М. Арноун, Б. Бархаєва, П. Щедровицького.

Питаннями особистісно орієнтованої освіти опікувались І. Бех, О. Бондаревська, А. Кіктенко, В. Кремень, О. Любарська О. Пєхота, С. Подмазін, О. Пометун, Г. Селевко, І. Якиманська.

Проблеми індивідуалізації навчання у закладах вищої освіти досліджували В. Галузинський, В. Гашимова, Т. Годованюк, С. Гончаренко, I. Зайченко, В. Крутецький, Ю. Мальований, Н. Мойсеюк. Тому метою нашої наукової розвідки $\epsilon$ теоретичне обгрунтування педагогічних умов формування індивідуальної освітньої траєкторії майбутніх педагогів у процесі професійної підготовки.

Виклад основного матеріалу. У довідкових джерелах поняття “умова” (condition) розглядається як: правила, які існують або встановлені в тій чи іншій галузі життя, діяльності, які забезпечують нормальну роботу чого-небудь [8]; сукупність явищ зовнішнього та внутрішнього середовища, що ймовірно, впливає на розвиток конкретного психічного явища; до того ж це явище опосередковується активністю особистості, групою людей (за 3. Курлянд) [9, 193]; необхідна обставина, що уможливлює здійснення, створення, утворення чого-небудь; обставини, особливості реальної дійсності, за яких відбувається або здійснюється що-небудь [1, 1506].

Отже, умову ми розуміємо як складник процесу професійної підготовки який впливає на формування індивідуальної освітньої траєкторії майбутніх педагогів.

У педагогіці умови визначають як чинники, обставини, від яких залежить ефективність функціонування педагогічної системи. Сучасна дидактика визначає умови як сукупність факторів, компонентів навчального процесу, що забезпечують успішність навчання.

Враховуючи той факт, що поняття “педагогічні умови” має велику кількість трактувань у педагогічних дослідженнях зупинимося на тих, які більшою мірою стосуються проблеми нашого дослідження.

За В. Стасюк, “педагогічні умови” - це обставини за яких залежить та відбувається цілісний продуктивний педагогічний процес професійної підготовки фахівців, що 
ТЕОРЕТИЧНЕ ОБГРУНТУВАННЯ ПЕДАГОГІЧНИХ УМОВ ФОРМУВАННЯ ІНДИВІДУАЛЬНОӤ ОСВІТНЬОЇ ТРАЄКТОРІЇ МАЙБУТНІХПЕДАГОГІВ В ПРОЦЕСІ ПРОФЕСІЙНОӤ ПДГОТОВКИ

опосередковується активністю особистості, групою людей $[9,193]$.

Учені О. Пєхота, В. Будак, А. Старева [7, 183] вважають, що педагогічні умови - це система, складовими якої є певні норми, методи, умови, ситуації, що об'єктивно склалися та є необхідними для досягнення певної педагогічної мети $[2,135]$.

Під педагогічними умовами А. Алексюк, А. Аюрзанайн, П. Підкасистий розуміють чинники, що впливають на процес досягнення мети, при цьому їх поділяють на: зовнішні “ позитивні відносини викладача і студента; об'єктивність оцінки навчального процесу; місце навчання, приміщення, клімат тощо; внутрішні (індивідуальні) “ індивідуальні властивості студентів (стан здоров'я, властивості характеру, досвід, уміння, навички, мотивація тощо) [4, 134].

У своєму дослідженні О. Ярошинська педагогічними умовами професійної підготовки майбутніх учителів початкової школи в проєктованому освітньому середовищі визначає сукупність взаємопов'язаних і взаємозумовлених об’єктивних можливостей, які забезпечують цілеспрямовану і систематичну координацію дій усіх його суб'єктів на основі об'єднання їх зусиль на поетапну реалізацію процедури проєктування 3 метою функціонування системи професійної підготовки як цілісної реальності, що забезпечує якісну підготовку майбутніх учителів [11, 264].

На думку К. Коновалової, використання поняття “педагогічні умови” пов'язане з необхідністю розв'язання різноманітних суто педагогічних проблем. Поняття “педагогічні" вказує, що означені обставини пов'язані з організацією освітнього процесу та необхідні для професійного становлення майбутніх вихователів закладів дошкільної освіти. Загальною особливістю всіх визначень $€$ спрямованість умов на підвищення ефективності розв'язання конкретних педагогічних завдань. Здійснюючи узагальнення наявних наукових позицій, педагогічні умови визначаємо як спеціально створені обставини, чинники, сукупність заходів, реалізація яких має забезпечити успішне формування складників професійної культури майбутніх вихователів закладів дошкільної освіти у процесі фахової підготовки і повноцінний прояв кожного з них [5, 134].

Зі свого боку Л. Колоніна педагогічну умову характеризує як взаємопов'язану сукупність обставин (внутрішніх параметрів та зовнішніх характеристик функціонування) засобів і заходів у педагогічному процесі, створених шляхом плідної співпраці між педагогом і майбутніми фахівцями, спрямованих на високу результативність професійної підготовки $[3,49]$.
Отже, педагогічні умови є результатом цілеспрямованого відбору, конструювання та застосування елементів змісту, методів (прийомів), а також організаційних форм навчання для досягнення дидактичних цілей.

При визначенні педагогічних умов формування індивідуальної освітньої траєкторії здобувача освіти слід врахувати той факт, що власний шлях освіти вибудовується для кожного студента стосовно кожної досліджуваної ним освітньої галузі. В основі вибору і побудови індивідуальної освітньої траєкторії в процесі професійної освіти лежать такі характеристики особистості: схильність до певного виду діяльності, потреба у професійному самовизначенні, готовність до професійного самовизначення.

Освітній процес за індивідуальними траєкторіями передбачає взаємодію викладача і студентів, при якому відбуваються поетапне проєктування і реалізація індивідуальних освітніх цілей, що супроводжується постійною діагностичної роботою з метою виявлення та обліку індивідуальних особливостей кожного студента, здійсненням рефлексії і корекції індивідуальних освітніх маршрутів і дотриманням необхідних педагогічних умов.

Спільна інтерсуб'єктна діяльність процесу проєктування індивідуальної освітньої траєкторії повинна здійснюватися у певній послідовності: педагог і студент як суб'єкти освітньої діяльності вибудовують, обговорюють, доповнюють уявлення про індивідуальну освітню траєкторії студента; здобувач освіти як суб'єкт навчання і педагог як фасилітатор поєднують свої уявлення і розробляють модель індивідуальної освітньої траєкторії; педагог упевнюється в тому, що студент розуміє сенс і приймає на себе відповідальність за результат вибору та реалізації індивідуального освітнього маршруту; в процесі спільної освітньої діяльності відбувається коригування індивідуальної освітньої траєкторії і маршруту здобувача освіти; при наявності проблемних ситуацій, які студент не може усунути самостійно, він звертається до педагога, тобто вони вступають в інтерсуб'єктну взаємодію; результатом реалізації індивідуального освітнього маршруту є успішне освоєння і засвоєння студентом основної освітньої програми закладу вищої освіти.

Вищеозначений алгоритм зумовлює зміст запропонованих нами педагогічних умов формування індивідуальної освітньої траєкторії для здобувачів професійної педагогічної освіти: педагогічний супровід формування індивідуальної освітньої траєкторії майбутніх педагогів в процесі 
ТЕОРЕТИЧНЕ ОБГРУНТУВАННЯ ПЕДАГОГІЧНИХ УМОВ ФОРМУВАННЯ ІНДИВІДУАЛЬНОӤ ОСВІТНЬОӤ ТРАЄКТОРЇ̈ МАЙБУТНІХПЕДАГОГІВ В ПРОЦЕСІПРОФЕСІЙНОЙ ПІДГОТОВКИ

професійної підготовки; посилення практичної спрямованості освітнього процесу; підвищення долі самостійної роботи здобувачів освіти у навчанні.

Педагогічний супровід формування індивідуальної освітньої траєкторії майбутніх фахівців має позитивний вплив на процес професійної підготовки завдяки ретельному проєктуванню означеного процесу (тобто вибудовування оптимальної траєкторії розгортання 3 урахуванням індивідуальних особливостей студентів), а також завдяки своєчасному наданню студентам необхідної допомоги з боку викладача, забезпечує оперативне повернення на визначену позицію у разі відхилення від неї.

Питання педагогічного супроводу досліджуються науковцями утаких напрямах: як умова модернізації самостійної роботи студентів (В. Квас); психолого-педагогічний супровід професійноособистісного розвитку педагога (А. Батаршев); організація педагогічного супроводу в освітньому середовищі (О. Ярошинська); форма здійснення пролонгованої соціальної та психологічної допомоги (Н. Осухова); психологічний супровід особистісно зорієнтованого виховання (I. Бех).

Педагогічний супровід як освітне явище характеризується такими ознаками: суб'єктсуб'єктний характер взаємодії викладача i студента; зорієнтованість на особистість студента, його потреби, бажання, мотиви, соціальну ситуацію розвитку; надання реальної допомоги в розроблення індивідуального плану дій, вироблення індивідуальної професійнопедагогічної стратегії $[6,128]$.

Педагогічний супровід повинен передбачати постійний моніторинг відповідності освітнього процесу заданій траєкторії розвитку; вимагає прямої участі педагога у процесі формування індивідуальної освітньої траєкторії; $\epsilon$ безперервним, не припиняється з розв'язком завдання; має комплексний характер та вимагає для своєї реалізації інтеграції знань, їх систематизації і адаптації до освітнього процесу закладу вищої освіти.

Отже педагогічний супровід передбачає проєктування індивідуальної освітньої траєкторії за таким алгоритмом: регламентація освітнього процесу з визначенням проміжних результатів які очікуються; добір і систематизацію навчальної інформації та завдань відповідно до індивідуальних запитів здобувачів освіти; визначення форм аудиторної і позааудиторної роботи з чітко визначеними етапами засвоєння матеріалу та видами навчальної діяльності; варіативність у виборі напрямів, форм, методів, способів організації освітньої діяльності.
Посилення практичної спрямованості освітнього процесу забезпечує реалізацію отриманих теоретичних знань та усвідомлення їх значущості у розкритті педагогічного “ $Я$ " i професійній самореалізації.

Реалізація педагогічної умови передбачає широке використання проблемних, дискусійних $\mathrm{i}$ моделюючих методів навчання, поглиблення міжпредметних зв'язків, збільшення кількості практичних педагогічних завдань, технологізацію висування освітніх цілей і оцінки результатів, поглиблення індивідуалізації навчання, застосування технологій змішаного навчання, застосування проєктної методики, активізацію отриманих теоретичних знань у процесі педагогічної практики,

У психолого-педагогічній літературі питанням практичної підготовки майбутніх фахівців присвячено низку досліджень: формування професійного інтересу у майбутніх учителів у процесі педагогічної практики (Л. Кацова); організаційно-методичні засади педагогічної практики майбутніх учителів початкової школи в умовах ступеневої підготовки (Н. Казакова); формування творчого стилю діяльності майбутніх педагогів у процесі педагогічної практики (Л. Манчуленко); формування професійної самореалізації майбутніх фахівців дошкільних закладів освіти у процесі педагогічної практики (М. Ярославцева).

Аналіз наукових розвідок дає змогу зробити висновки, що педагогічна практика в силу іiі специфіки є найбільш практико-орієнтованою формою організації навчальної діяльності і забезпечує розвиток суб'єктності майбутнього фахівця як основної передумови проєктування індивідуальної освітньої траєкторії.

Як зазначає М. Ярославцева, система практик буде досконалою, якщо будуватиметься 3 урахуванням принципів організації (взаємозв'язок і взаємопроникнення теоретичної підготовки і практичної діяльності студентів, інтеграція їх навчальної і дослідницької діяльності; забезпечення спадкоємності, систематичності, безперервності педагогічної практики; поєднання педагогічного контролю, колективного аналізу діяльності студентів і їх самоконтролю, самоаналізу і самооцінки; варіативного вибору змісту і форм діяльності студентів у період практики; організація цілісного керівництва педагогічною практикою студентів та взаємодія професійно-педагогічних освітніх установ) i забезпечуватиме підготовку педагога як професійно-компетентного фахівця-дослідника $[10,10]$. 


\section{ТЕОРЕТИЧНЕ ОБГРУНТУВАННЯ ПЕДАГОГІЧНИХ УМОВ ФОРМУВАННЯ ІНДИВІДУАЛЬНОЙ}

ОСВІТНЬОӤ ТРАЄКТОРІЇ МАЙБУТНІХПЕДАГОГІВ В ПРОЦЕСІ ПРОФЕСІЙНОӤ ПІДГОТОВКИ

Збільшення долі самостійної роботи в освітньому процесі забезпечує усвідомлене засвоєння навчального матеріалу і забезпечує ефективне просування здобувачів освіти за індивідуальним освітнім маршрутом до більш високих щаблів професіоналізму.

Серед технологій, орієнтованих на організацію самостійної роботи, можна виокремити такі: кредитно-модульна технологія (О. Пєхота, П. Сікорський); фреймова технологія (Р. Гуріна, Т. Колодочка, Л. Лузінова, Л. Панасенко, О. Соколова, М. Холодна та ін.); MultiMediaтехнології(А. Білан, I. Костікова, О. Панасюк); технологія дистанційного навчання (В. Кремень, В. Кухаренко, С. Полат); технологія рівневої диференціації (А. Бібік, Л. Зоріна, М. Кашин, Л. Фрідман); технологія індивідуалізації навчання (В. Загвязинський, Г. Селевко), технологія імовірнісної освіти (О. Лобко); проєктна технологія (В. Беспалько, О. Пєхота); технологія оптимізації навчального процесу (Ю. Бабанський); технологія розвивального навчання (Л. Занков); технологія адаптивного навчання (А. Граніцкий) та інші.

Організація самостійної роботи формує у студента на кожному етапі його руху від незнання до знання, навички та вміння, необхідні для розв'язання певних пізнавальних завдань, забезпечуючи цим рух індивідуального освітнього траєкторією.

Індивідуальні завдання допомагають виробити у студентів психологічну установку на систематичне поповнення знань, забезпечують виховання самоорганізації та самодисципліни в оволодінні професійними знаннями та навичками, здійснюють суттєвий вплив на підвищення академічної успішності, що є стимулом до подальшого формування індивідуальної освітньої траєкторії.

У процесі організації самостійної роботи у здобувачів освіти формуються переконання про важливість отримання не лише професійних знань, а й формування навичок soft skills, які формуються у процесі опанування освітніми компонентами гуманітарного та суспільного спрямування.

Також самостійна робота яка переходить у самоосвіту та самовиховання, має більше виховане значення, оскільки формує у майбутніх фахівців самостійність, цілеспрямованість, вміння досягати намічені цілі у просуванні індивідуальним освітнім маршрутом.

Організація самостійної роботи повинна здійснюватись за такими напрямами: дослідження форм та методів активізації самостійної навчальної діяльності; аналіз обсягу та структури поза аудиторної самостійної роботи за весь період теоретичного навчання у закладі вищої освіти; дослідження та розробка способів планування й організації позааудиторної самостійної роботи у бюджеті часу студентів; розробка методики формування у майбутніх фахівців культури розумової праці та навичок роботи зі спеціальною літературою.

Висновки. Таким чином, реалізація педагогічних умов формування індивідуальної освітньої траєкторії майбутніх фахівців у процесі професійної підготовки дає змогу виявити рівень здібностей здобувачів освіти, трансформувати теоретичне знання у практичну діяльність, сформувати первинний досвід самовиховання та самонавчання, опанувати знання стосовно розвитку особистісного потенціалу підростаючого покоління.

\section{ЛІТЕРАТУРА}

1. Великий тлумачний словник сучасної української мови (з дод., допов.) / уклад. і голов. ред. В. Т. Бусел. Київ : Ірпінь: ВТФ, “Перун”, 2009. $1736 \mathrm{c}$.

2. Гора Н.В. Педагогічні умови формування професійної компетентності майбутніх товарознавців. Молодий вчений. 2018 р. № 6 (58) C. $132-138$.

3. Колоніна Л. Г. Особливості організаційнопедагогічних умов формування індивідуальної освітньої траєкторії майбутнього вчителя музики у процесі професійної підготовки. URL: https:// media.neliti.com/media/publications/321117особливості-організаційно-педагогічних-у64711631.pdf (дата звернення 10.09.2021 р.).

4. Коновалова К. І. Модель формування професійної культури майбутніх вихователів дошкільних навчальних закладів у процесі фахової підготовки. Збірник наукових праць Уманського державного педагогічного університету імені Павла Тичини. 2017. Вип. 1. С. 184-191.

5. Коновалова К.І. Формування професійної культури майбутніх вихователів закладів дошкільної освіти у процесі фахової підготовки. дис. канд. пед. наук : 13.00.04 / Державний заклад "Південноукраїнський національний педагогічний університет імені К. Д. Ушинського”, Одеса, 2018. $309 \mathrm{c.}$

6. Мирончук Н.М. Педагогічний супровід майбутніх викладачів вищої школи у процесі професійної підготовки. Нові технологіi навчання. Інститут інноваційних технологій і змісту освіти МОН України. 2016. Вип. 89. Частина 2. С. 127-131.

7. Підготовка майбутнього вчителя до впровадження педагогічних технологій / за ред. 
I. А. Зязюна, О. М. Пєхоти. Київ : А.С.К., 2003. $240 \mathrm{c}$.

8. Словник української мови. URL: http:// sum.in.ua (дата звернення: 12.08.2021 р.).

9. Словник-довідник з професійної педагогіки / За ред. А.В. Семенової. Одеса : Пальміра, 2006. URL: https://www.pedagogic-master.com.ua/public/ semenova/slovnik.pdf(дата звернення: 12.08.2021 p.).

10. Ярославцева М.І. Формування професійної самореалізації майбутніх фахівців дошкільних навчальних закладів у процесі педагогічної практики : автореф. дис. ... к-та пед. наук : 13.00 .04 / ДВНЗ “Переяслав-Хмельницький державний педагогічний університет імені Григорія Сковороди". Харків, 2015. 24 с.

11. Ярошинська О. О. Теоретичні і методичні засади проектування освітнього середовища професійної підготовки майбутніх учителів початкової школи. дис. докт. пед. наук : 13.00.04 / Уманський державний педагогічний університет імені Павла Тичини, Умань, 2015. 544 с.

\section{REFERENCES}

1. Velykyi tlumachnyi slovnyk suchasnoi ukrainskoi movy (2009). [Large explanatory dictionary of the modern Ukrainian language]. (Ed.).V. T. Busel. Kyiv, 1736 p. [in Ukrainian].

2. Hora, N.V. (2018). Pedahohichni umovy formuvannia profesiinoi kompetentnosti maibutnikh tovaroznavtsiv [Pedagogical conditions for the formation of professional competence of future commodity experts]. A young scientist. No.6 (58) pp. 132-138. [in Ukrainian].

3. Kolonina, L. H. Osoblyvosti orhanizatsiinopedahohichnykh umov formuvannia indyvidualnoi osvitnoi traiektorii maibutnoho vchytelia muzyky u protsesi profesiinoi pidhotovky [Peculiarities of organizational and pedagogical conditions of formation of individual educational trajectory of future music teacher in the process of professional training]. Available at: https://media.neliti.com/media/ publications/321117-osoblyvosti-orhanizatsiinopedahohichnykh-u-64711631.pdf(accessed 10 Sept. 2021) [in Ukrainian].

4. Konovalova, K. I. (2017). Model formuvannia profesiinoi kultury maibutnikh vykhovateliv doshkilnykh navchalnykh zakladiv u protsesi fakhovoi pidhotovky [Model of formation of professional culture of future educators of preschool educational institutions in the process of professional training]. Collection of scientific works of Uman State Pedagogical University named after Pavlo Tychyna. Vol. 1. pp. 184-191. [in Ukrainian].

5. Konovalova, K.I. (2018) Formuvannia profesiinoi kultury maibutnikh vykhovateliv zakladiv doshkilnoi osvity u protsesi fakhovoi pidhotovky [Formation of professional culture of future educators of preschool education institutions in the process of professional training]. Candidate's thesis. Odesa, 309 p. [in Ukrainian].

6. Myronchuk, N.M. (2016). Pedahohichnyi suprovid maibutnikh vykladachiv vyshchoi shkoly u protsesi profesiinoi pidhotovky [Pedagogical support of future high school teachers in the process of professional training]. New learning technologies. Institute of Innovative Technologies and Educational Content of the Ministry of Education and Science of Ukraine. Vol. 89, part 2.pp. 127-131. [in Ukrainian].

7. Pidhotovka maibutnoho vchytelia do vprovadzhennia pedahohichnykh tekhnolohii (2003). [Preparation of the future teacher for introduction of pedagogical technologies]. (Ed). I. A. Ziaziuna, O. M. Piekhoty. Kyiv, 240 p. [in Ukrainian].

8. Slovnyk ukrainskoi movy [Dictionary of the Ukrainian language]. Available at: http://sum.in.ua (accessed 12 Aug. 2021) [in Ukrainian].

9. Slovnyk-dovidnyk z profesiinoi pedahohiky (2006). [Dictionary-reference book on professional pedagogy]. (Ed.). A.V. Semenovoi. Odesa. Available at: https://www.pedagogic-master.com.ua/public/ semenova/slovnik.pdf (accessed 12 Aug. 2021) [in Ukrainian].

10.Iaroslavtseva, M.I. (2015). Formuvannia profesiinoi samorealizatsii maibutnikh fakhivtsiv doshkilnykh navchalnykh zakladiv u protsesi pedahohichnoi praktyky [Formation of professional self-realization of future specialists of preschool educational institutions in the process of pedagogical practice]. Extended abstract of candidate's thesis. Kharkiv, 24 p. [in Ukrainian].

11. Iaroshynska,O. O. (2015). Teoretychni i metodychni zasady proektuvannia osvitnoho seredovyshcha profesiinoi pidhotovky maibutnikh uchyteliv pochatkovoi shkoly [Theoretical and methodical bases of designing the educational environment of professional training of future primary school teachers]. Doctor's thesis. Uman, 544 p. [in Ukrainian].

Стаття надійшла до редакції 04.10.2021

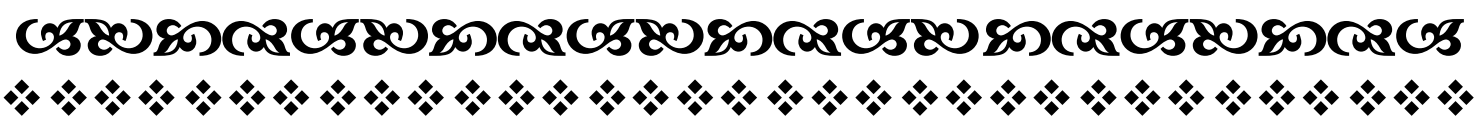

